\title{
Stap vooruit in onderzoek naar preventie
}

\author{
E. Dera-de Bie
}

Published online: 12 May 2020

(C) Bohn Stafleu van Loghum is een imprint van Springer Media B.V., onderdeel van Springer Nature 2020

Door de coronapandemie is 2020 een jaar geworden waarin preventieve maatregelen essentieel blijken om ziekten te voorkomen. Hierbij doet de regering een groot beroep op de eigen verantwoordelijkheid van de burger. Maatregelen als sociale afstand houden, thuisblijven en handen wassen zijn inmiddels bij iedereen bekend. De maatregelen worden geregeld herhaald en op een redelijke korte termijn zag het merendeel van de bevolking het belang en de urgentie ervan in. Bij de bestrijding van het coronavirus komen verschillende varianten van preventie aan bod: preventie naar ziektefase, doelgroep, maatregel of interventiemethode. Al deze vormen blijken van belang bij het bestrijden van deze pandemie. Tussen de diverse landen is er enige diversiteit te zien in de aanpak, niet alleen door de ernst van de pandemie, maar ook door culturele verschillen.

Door een gebrek aan kennis over het virus werden in hoog tempo veel nieuwe onderzoeksinitiatieven gestart om de negatieve gevolgen zo snel mogelijk in te dammen. Zo wordt onderzocht wat de rol van kinderen is bij de verspreiding van het virus. Van oudsher is de jeugdgezondheidszorg bekend met infectieziektepreventie, maar tegenwoordig is die expertise uitgebreid naar de volledige basiszorg voor de jeugd.

De laatste decennia is kennis verworven over het preventief bevorderen van de gezondheid bij kinderen. De adviezen over veilig slapen zijn een bekend voorbeeld. Toch zijn nog veel vragen onbeantwoord.
In Nederland slapen baby's soms buiten, maar is er weinig bekend over de voor- en nadelen van deze praktijk. Floortje Kanis voerde een verkennend onderzoek uit. Meer onderzoek is wenselijk om inzicht te krijgen in de voorwaarden voor het veilig slapen van baby's in de buitenlucht en adviezen daarop aan te passen. In relatie tot de preventie van kindermishandeling onderzochten Simeon Visscher en collega's of er een verschil in kennis, vaardigheden en persoonlijke kenmerken is tussen de professionals die deze taak uitvoeren. In de proefschriftbespreking van Marieke van Wijk komt het preventieve 'spalken' van aangeboren en verworven oorschelpafwijkingen om cosmetische redenen aan bod. Ten slotte laat Dominique-Jean Bouillez zien dat een bipolaire stoornis al in de kindertijd of adolescentie ontstaat, maar dat het vaak jaren duurt voordat de diagnose wordt gesteld. Ook gaat hij in op de samenhang tussen een bipolaire stoornis en $\mathrm{AD}(\mathrm{H}) \mathrm{D}$, en de mogelijkheid om stemmingswisselingen eerder op te sporen aan de hand van predictieve factoren. Uit dit onderzoek blijkt dat het vroeger starten met een behandeling betere resultaten oplevert.

De kanteling van cure naar care, met een specifieke rol voor preventie, verloopt moeizaam, maar verdient wel aandacht. Preventie staat steeds vaker op de agenda en heeft zich niet alleen in het verleden, maar ook in het heden, bewezen. 